\title{
PENGEMBANGAN PROFESIONALISME GURU MELALUI PELATIHAN PENGEMBANGAN TES, KONSTRUKSI DAN ANALISIS BUTIR SOAL DI WILAYAH 2T
}

\author{
Muhsinah Annisa ${ }^{1}$, A.Wilda Indra Nanna ${ }^{2}$, Ahsan Sofyan ${ }^{3}$, Dedi Kusnadi ${ }^{4}$ \\ Universitas Borneo Tarakan ${ }^{1,2,3,4}$ \\ echa.ok@gmail.com ${ }^{1}$,wiradjab@gmail.com², sofyanituahsan@gmail.com³ \\ dedikusnadi4289@gmail.com ${ }^{4}$
}

\begin{abstract}
ABSTRAK
Guru profesional harus memiliki 4 kompetensi, salah satunya yaitu kompetensi pedagogik, dalam kompetensi pedagogik, salah satu aspek yang harus dimiliki oleh seorang guru yaitu dalam melakukan penilaian dan evaluasi. Hal ini mengacu pada Permendikbud No. 66 tahun 2013 bahwa penilaian yang dibuat harus berdasarkan acuan penilaian bagi pendidik, satuan pendidikan dan pemerintah pada satuan pendidikan dasar dan menengah. Berdasarkan wawancara dengan guruguru di SDN 004 Malinau Barat, terdapat permasalahan dalam pembuatan soal. guru belum mengikuti kaidah penulisan soal, hal itu menyebabkan hasil belajar siswa belum sesuai dengan kompetensi yang diharapkan. Pelatihan Pengabdian Masyarakat menggunakan metode ceramah, penugasan dan diskusi serta pendampingan pembuatan kisi-kisi soal dan penyusunan soal. Langkah-langkah kegiatan yaitu dengan pelatihan berupa teori, penugasan secara mandiri dan diskusi. Sasaran kegiatan ini adalah guru-guru sekolah dasar di Kabupaten Malinau. Data angket yang diberikan kepada peserta menunjukkan bahwa 58,3\% merupakan hal yang baru, $75 \%$ pelatihan ini sangat membantu dalam pelaksanaan tugas, 100\% peserta memperoleh tambahan pengetahuan dan keterampilan dan pelatihan sangat efektif. 91,3\% mengatakan waktu seimbang dengan materi dan, dan $100 \%$ menyatakan perlu ada pelatihan lanjutan.
\end{abstract}

Kata Kunci: Pelatihan, Tes, Guru, Wilayah 2 T

\section{ABSTRACT}

Professional teachers should have 4 main competences, one of which is pedagogical competence. One of its sub-competencies needed by the teachers is the ability to contruct learning assessment instruments. Based on interviews to the teachers at SDN 004 West Malinau, it was found problems associated In addition, in constructing the test items, the teachers did not follow the rules of test writing, so that the learning achievement of the students was not described the whole competencies as required. This Community Service Training was conducted using lecturing method, assignments, and discussion as well as assisting in making table of test specification and writing test items. The stages of activities were by training the teachers with a theoretical concepts, individual assignments, and discussion. The data from the questionnaire given to the teachers showed that $58.3 \%$ said that this kind of training was a new thing for them, $75 \%$ answered that it was very helpful for their tasks as teachers, $100 \%$ of participants acquired additional knowledge and skills and training was very effective. $91.3 \%$ said the time allocation was in accordance with the material and assignments, and 100\% expressed that they needed for further training.

Keywords: Training, Test, Teacher, $2 T$ areas

\section{PENDAHULUAN}

Kalimantan Utara merupakan provinsi yang berbatasan langsung dengan negara tetangga, yaitu Negara Bagian Sabah dan Serawak, Malaysia Timur. Sebagai provinsi baru yang berbatasan langsung dengan negara lain, Kalimantan Utara mempunyai peranan yang sangat penting dalam menjaga eksistensi negara Indonesia. Salah satu bagian penting dalam pembangunan SDM adalah bidang pendidikan. Hal ini 
senada dengan pembukaan UUD 1945 mengamanatkan bahwa pembentukan pemerintahan negara indonesia yaitu salah satunya adalah untuk mencerdaskan kehidupan bangsa, untuk mewujudkannya maka diatur dalam UUD 1945 Pasal 31 ayat 3 yang menyatakan bahwa pemerintahan mengusahakan dan menyelenggarakan satu sistem pendidikan nasional, yang meningkatkan keimanan dan ketakwaan serta akhlak mulia dalam rangka mencerdaskan kehidupan bangsa, yang diatur dalam undang-undang.

Salah satu bagian yang sangat berperan dalam mencerdaskan kehidupan bangsa adalah guru. Profesi guru Guru merupakan bagian yang sangat penting, yaitu profesi yang memiliki keahlian dan kewenangan khusus dalam bidang pendidikan, pengajaran dan pelatihan (Kunandar, 2007). Usman (2006) juga menyatakan bahwa guru profesional adalah orang yang memiliki kemampuan dan keahlian khusus dalam bidang keguruan sehingga ia mampu melakukan tugas dan fungsinya sebagai guru dengan kemampuan maksimal. Setiap guru diharapkan mampu mencapai kriteria guru yang kompeten, seperti yang tertuang dalam Permendiknas No. 16 Tahun 2007, bahwa standar kompetensi yang harus dimiliki guru terdiri dari kompetensi pedagogik, kepribadian, sosial dan profesional (Annisa, 2017).

Dalam kompetensi pedagogik, salah satu aspek yang harus dimiliki oleh seorang guru yaitu dalam melakuakan penilaian dan evaluasi. Sebelum melakukan evaluasi, maka guru harus melakukan penilaian yang didahului dengan pengukuran (Mardapi, 2012). Hal ini mengacu pada Permendikbud No. 66 tahun 2013 bahwa penilaian yang dibuat harus berdasarkan acuan penilaian bagi pendidik, satuan pendidikan dan pemerintah pada satuan pendidikan dasar dan menengah.
Penilaian hasil belajar peserta didik dilaukan secara kesinambungan dan digunakan untuk mengukur ketercapaian kompetensi sesuai standar kompetensi lulusan yang dituntut, dan dilakukan secara serempak yaitu dengan dilakukannya ujian nasional.

Ujian Nasional dilaksanakan serentak di seluruh Indonesia, tak terkecuali di Kalimantan Utara, sebagai daerah yang merupakan provinsi termuda di Indonesia, Kalimantan utara terus berupaya menuju perubahan yang lebih baik, salah satunya di bidang pendidikan. Proses pembelajaran di Kalimantan Utara sangat bervariasi, karena Kalimantan Utara terdiri dari wilayah perkotaan, pedalaman, pesisir dan kabupaten, dan ada juga yang termasuk dalam daerah $2 \mathrm{~T}$ (terdepan dan terluar), proses pembelajaran antara daerah perkotaan dan daerah 2T terdapat perbedaan, baik dari segi sumber daya manusia manupun fasilitasnya. Salah satu daerah yang merupakan daerah terdepan dan terluar adalah Kabupaten Malinau. Kabupaten Malinau merupakan salah satu wilayah yang cukup banyak penempatan guru SM3T.

Berdasarkan wawancara dengan guru-guru di SDN 004 Malinau Barat, ditemukan permasalah yang terkait dengan penulisan soal, yaitu guru-guru belum mengikuti kaidah penulisan soal sehingga hasil belajar peserta didik belum menggambarkan kompetensi yang dituntut. Hal ini disebabkan oleh pemahaman guru belum memadai dalam penyusunan instrument soal dan penulisan soalnya.

Beberapa fakta yang didapat berdasarkan hasil wawancara adalah sebagai berikut.

1. Persentase guru SD yang memiliki latar pendidikan sarjana baru sekitar di bawah 40 $\%$, dan selebihnya masih berlatar pendidikan SPG dan SMA. Selain itu Pertemuan KKG hanya diadakan 1 kali dalam 1 
semester, sehingga jarangnya pertukaran informasi terbaru tentang dunia pendidikan, selain itu juga mempengaruhi lambatnya penyampaian informasi terkini tentang perkembangan pendidikan.

2. Dalam membuat soal, guru masih terlalu bergantung dengan pihak lain, guru hanya meniru contoh yang dibuat oleh orang lain atau dari lembar kegiatan siswa (LKS) yang ada.

3. Ketika membuat atau mengembangkan soal, guru tidak membuat kisi-kisi dan tidak mengikuti kaidah-kaidah penulisan soal yang baik dan benar.

4. Guru tidak melakukan analisis butir soal, sehingga guru tidak mengetahui indikator yang belum tercapai, dan juga adanya ketidaksesuaian antara indikator dengan soal yang dibuat.

Berdasarkan beberapa fakta di atas yang merupakan sebagian kecil dari permasalahan-permasalahan yang terjadi di bidang pendidikan, maka pengusul bersama dengan guru SDN menimbang perlu dilaksanakan kegiatan pelatihan guru dalam kegiatan pelatihan penyusunan tes, butir soal dan konstruksi butir soal.

\section{METODE PELAKSANAAN}

Prosedur pelaksanaan yang digunakan adalah sebagai berikut. yang akan digunakan adalah sebagai berikut:

1. Sebelum berangkat ke lokasi mitra, pengusul menghubungi kepala sekolah SDN 004 Malinau Barat untuk meminta kesiapan pelaksanaan kegiatan pelatihan di sekolah mereka.

2. Dosen pelaksana mempersiapkan materi penyusunan tes dan konstruksi butir soal.
3. Pelatihan penyusunan butir tes dan konstruksi butir soal dilakukan dengan metode ceramah, diskusi, tanya jawab dan pendampingan kelompok yang dibagikan berdasarkan jenjang kelas di sekolah.

\section{HASIL}

Kegiatan pelatihan pengembangan tes, konstruksi dan analisis butir di wilayah $2 \mathrm{~T}$ berjalan lancar. Peserta yang berjumlah 25 guru terlibat aktif selama proses pelatihan berlangsung. Peserta dibagi dalam beberapa kelompok berdasarkan jenjang kelas yang diampu oleh guru tersebut. Guru berlatih bagaimana mengembangkan tes dengan dibimbing oleh tim dosen pengabdian.

Data respon guru setelah mengikuti pelatihan disajikan pada Gambar 1 berikut.

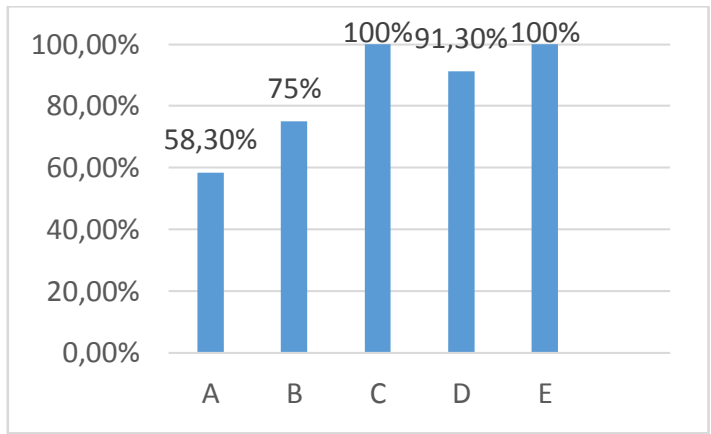

Keterangan :

A. Pelatihan merupakan hal yang baru

B. Pelatihan membantu dalam pelaksanaan tugas

C. Peserta memperoleh tambahan pengetahuan dan keterampilan.

D. Waktu seimbang dengan materi dan tugas.

E. Perlu ada pelatihan lanjutan.

Berdasarkan angket respon yang diberikan setelah kegiatan pelatihan. Masih banyak guru yang belum pernah mendapatkan pelatihan, sehingga pelatihan ini merupakan hal baru bagi mereka. Akses daerah $2 \mathrm{~T}$ yang merupakan daerah terdepan dan terluar membuat hanya sebagian yang bisa 
mendapatkan pelatihan-pelatihan yang dapat menunjang tugas profesi guru. Pelatihan ini sangat membantu guru yang dalam menambah pengetahuan dan keterampilan mereka, sehingga diharapkan ada pelatihan yang dapat membantu guru dalam melaksanakan tugas mereka.

\section{PEMBAHASAN}

Kegiatan pelatihan ini didahului dengan wawancara dengan guru dan kepala sekolah SDN 004 Malinau selatan, didapat permasalahan yaitu guru kurang terampil dalam membuat soal. Metode yang dilakukan dalam pelatihan ini yaitu dengan ceramah, diskusi dan pendampingan pembuatan instrumen tes. Dalam kegiatan pelatihan, diawali dengan brain storming tentang bagaimana cara guru dalam mengukur hasil belajar siswa, yaitu selama ini guru membuat soal hanya dengan melihat dari buku ajar dan LKS yang ada, selain itu guru menggunakan soal yang dimiliki guru sejak bertahun-tahun lalu tanpa adanya variasi dalam membuat dan mengembangkan soal.

Berdasarkan kondisi tersebut, maka dalam pelatihan ini dilakukan dengan metode ceramah untuk memperdalam pemahaman tentang pengembangan tes, konstruksi dan analisis butir soal dilanjutkan dengan diskusi. Guru diajarkan bagaimana mngembangkan tes, baik tes untuk hasil belajar kognitif, selain itu diajarkaan juga cara mengembangkan penilaian untuk hasil belajar afektif dan psikomotorik. Dalam kegiatan pelatihan, peserta dikelompokkan berdasarkan jenjang kelas dan peserta mempraktekkan pembuatan tes dan kisi-kisi soal, guru diajarkan bagaimana menyusun tes berdasarkan kesesuaian indikator seperti pada gambar 1 berikut.

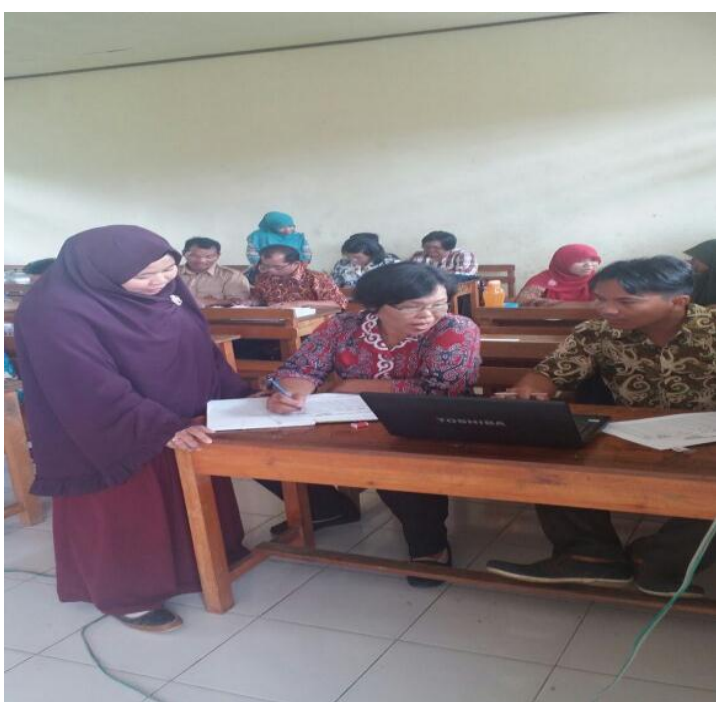

Gambar 1. Tim Dosen membimbing guru dalam Diskusi

Dalam pembuatan soal yang baik, hendaknya guru memiliki kemampuan literasi yang baik. Literasi meliputi beberapa jenis, diantaranya literasi dasar, literasi numerik dan literasi sains. Literasi sains (Scientific literacy) akhir-akhir ini sedang menjadi pusat perhatian dan penelitian

di dunia pendidikan (Annisa, 2017). Dengan kemampuan literasi guru yang baik, diharapkan guru juga dapat memiliki pemahaman konsep yang benar, sehingga tidak mengalami miskonsepsi dalam pembeajaran maupun dalam pembuatan soal.

Berdasarkan diskusi dengan peserta pelatihan, banyak guru yang memiliki konsep yang keliru terkait dengan materi, misalnya dalam mata pelajaran IPA. Hal ini diperkuat oleh Annisa (2017) yang menyatakan bahwa sebagian responden (guru) di daerah 4P, salah satunya di wilayah pedalaman, kurang memiliki pemahaman tentang aspek-aspek hakikat sains. Kurangnya pemahaman guru mengenai hakikat sains dapat menyebabkan timbulnya miskonsepsi, hal ini juga diperkuat oleh Annisa (2017) yang menyatakan bahwa miskonsepsi yang terjadi di kalangan guru di wilayah pedalaman berasal dari pemikiran guru itu sendiri dan buku referensi yang digunakan guru. 
Berdasarkan wawancara yang dilakukan terhadap peserta pelatihan, mereka sangat antusias terhadap kegiatan pelatihan ini. Guru yang menjadi peserta baru pertama kali mendapatkan pelatihan dengan materi tentang pengembangan tes, konstruksi dan analisis butir soal. Para peserta pelatihan memperhatikan dengan seksama dan mencatat materi-materi penting, dan aktif bertnya jika ada hal yang kurang dimengerti. Mayoritas guru juga belum mendapatkan pengetahuan tentang pembuatan kisi-kisi soal, hal itu dikarenakan latar belakang mereka $85 \%$ masih berlatarbelakang SMA, dan mereka juga jarang terlibat dalam kegiatan pelatihan yang diadakan oleh Dinas Pendidikan Setempat. Mengingat daerah mereka cukup jauh dari daerah Kota. Selain itu dengan adanya pelatihan ini, mereka sangat terbantu dalam menyelesaikan tugas mereka, karena salah satu tugas guru yaitu menyusun instrumen tes yang digunakan untuk mengukur hasil belajar siswa setelah proses pembelajaran berlangsung. Dalam pembuatan soal, guru jarang mengacu pada indikator penilaian atau indicator pengembangan kompetensi. Selama ini mereka menyusun soal hanya melihat dari buku cetak atau LKS, tanpa mengetahui kaidah-kaidah dalam membuat soal yang benar.

Proses terakhir yang dilakukan setelah pelatihan yaitu dengan memberikan umpan balik kepada peserta. Peserta diminta untuk mengisi angket respon terhadap kegiatan pelatihan tersebut. Data angket menunjukkan bahwa 58,3\% merupakan hal yang baru. Hal ini dikarenakan, wilayah mereka yang cukup jauh dari perkotaan membuat akses nformasi menjadi terbatas. Hanya sebagian kecil guru yang pernah mendapatkan pelatihan pembuatan soal. Semua peserta sangat mengharapkan adanya pelatihan lanjutan, karena pelatihan seperti ini sangat membantu mereka dalam mengerjakan tugas mereka, yaitu dalam mengembangkan soal yang akan diberikan kepada siswa.

Berdasarkan hasil evaluasi, kegiatan pengembangan tes, konstruksi dan analisis butir soal dapat berhasil dengan baik. peserta antusias dan mulai memahami cara mengembangkan tes dengan baik. hal ini terlihat dengan hasil tugas guru yang dilakukan pada saat pelatihan berlangsung.

\section{PENUTUP}

a. Kesimpulan

Setelah dilakukan kegiatan ini berdasarkan angket evaluasi dari peserta kegiatan dapat disimpulkan bahwa kegiatan pelatihan ini sangat bermanfaat bagi guru Sekolah Dasar khususnya guru di Sekolah Dasar di Malinau. Bertambahnya pengetahuan dan keterampilan guru dalam mengembangkan tes, konstruksi dan analisis butir soal, yang mana hal ini dapat membantu guru dalam melaksanakan tugasnya.

b. Saran

Berdasarkan saran-saran yang disanpaikan, maka perlu ada kegiatan berkelanjutan agar pemahaman mereka lebih komprehensif.

\section{DAFTAR PUSTAKA}

Annisa, Muhsinah, \& Hamid, H. (2017). Pengembangan profesionalisme guru melalui pelatihan penyusunan karya tulis ilmiah di wilayah pedalaman. Widya laksana, 5(2), 81-84.

Annisa, M. (2017). Pemahaman AspekAspek dalam Hakikat Sains (Nature of Science) oleh Guru Sekolah Dasar di Wilayah 4P (Pedalaman, Perbatasan, Perkotaan, dan Pesisir). Jurnal Ilmiah Sekolah Dasar, 1(4), 241-246.

Annisa, Muhsinah. The misconceptionsof natural science (IPA) in primary school teachers in rural areas of north kalimantan. 2nd icet theme: "improving the quality of 
education and training through strengthening networking”, 604.

Annisa, M., \& Listiani, M. (2017).

Elementary School Teachers'

Understanding of Nature of Science: A Study on Rural, Bordered, Coastal, and Urban Areas of North Kalimantan. In 1st International Conference on Social Sciences Education-" Multicultural Transformation in Education, Social Sciences and Wetland Environment"(ICSSE 2017). Atlantis Press.

Kunandar. (2007) Guru Profesional Implementasi Kurikulum Tingkat Satuan Pendidikan (KTSP) dan Persiapan Menghadapi Sertifikasi Guru. Jakarta: PT Raja Grafindo Persada.

Mardapi, Djemari. 2012. Pengukuran, Penilaian, Evaluasi Pendidikan. Yogyakarta: Nuha Medika

Undang-undang Dasar 1945 Pasal 31 Ayat 3

Usman, M. Uzer. 2006. Menjadi Guru Profesional, Bandung: PT. Remaja Rosda Karya 